\title{
GOVERNANCE NETWORKS FOR EFFECTIVE CUSTODIANS' PARTICIPATION IN THE SUSTAINABILITY OF LANGKAWI AS A GEOPARK
}

\section{Geraldine K. L. Chan}

School of Social, Development and Environmental Studies, Faculty of Social Sciences and Humanities, Universiti Kebangsaan Malaysia, MALAYSIA E-mail: geralckl@ukm.edu.my

Published online: 29 December 2017

To cite this article: Geraldine K. L. Chan. 2017. Governance networks for effective custodians' participation in the sustainability of Langkawi as a geopark. Kajian Malaysia 35(Supp.1): 91-118. https://doi.org/10.21315/km2017.35.Supp.1.6

To link to this article: https://doi.org/10.21315/km2017.35.Supp.1.6

\section{ABSTRACT}

The Global Geopark Networks (GGN) created the concept of "geopark" as a geographically designated area that contains geological, ecological, historical cultural resources for community sustainable development primarily through tourism activities. The Langkawi archipelago has always been rich in such resources and heritage, and was conferred the geopark status by GGN in 2007. Since then, the government and some private, non-governmental organisations have been involved in many geopark projects and activities. Some of them are members of the top down governance system while other parties work independently of one another. For Langkawi to sustain in the long run as a successful and economically developed geopark without the depletion of its geological, ecological, cultural and historical resources, its governance system can be further improved. Effective custodian participation is best achieved through proper governance network system whereby the networks are established between at least two or more organisational and non-organisational custodians irrespective of their social status, ethnicity, gender, wealth and income levels. Specifically, the custodians should work closely together and establish networks in a transparent, accountable, responsible, fair, trustworthy and consistent manner. Effective participation should be in terms of shared norms of behaviour such as cooperation, assistance and influence. Furthermore, such effective participation is based on shared views, shared values, shared norms and other shared aspects guided to some extend by basic network principles such as reciprocity and mutuality. This implies that similarity or commonality is a key feature in social networks formation of the custodians. Trust is also present as a 
network element. For Langkawi to sustain as a geopark in present and future times, effective participation from all custodians can be achieved through governance networks or social networks. This paper will present some findings from two empirical studies conducted on effective governance networks for the success of Langkawi as a geopark.

Keywords: governance, governance networks, social networks, sustainability, custodians

\section{INTRODUCTION}

Global Geopark Networks (GGN), a network formed as an initiative under the United Nations, created the concept of geopark. For GGN, a geopark is a geographically designated area that contains geological, ecological, historical and cultural resources for community sustainable development primarily through tourism activities (Global Geoparks Network, n.d.). The Langkawi archipelago in the northern Peninsular Malaysia has always been rich in such resources, and was declared a geopark by GGN in 2007.

Malaysia is proud to have Langkawi as its first geopark. Since 2007, the government, private sectors, non-governmental organisations (NGOs) and local communities have been involved in many geopark programmes, projects and activities related to heritage conservation and sustainable development mainly through tourism and eco-tourism. Some of the parties mentioned became involved through the top down governance system while other parties work together in a bottom up approach, or independently of one another for specific projects and activities. Community participation in geopark related tourism and eco-tourism activities and projects are no longer unheard of in Langkawi.

However, for Langkawi to sustain effectively in the long run as a successful and economically sustainable developed geopark without the depletion of its resources, its governance of heritage conservation and sustainable development through tourism need to be further improved through continuous active cooperation between all parties. A geopark that is developed through effective custodian cooperation can contribute to improved local socio-economic growth; specifically, cooperation that is based and sustained through governance networks between the custodians. The governance networks are social networks in nature; hence, the terms "social networks", "networks" and "governance networks" are used interchangeably throughout this article. 


\section{ISSUE AND SIGNIFICANCE OF GOVERNANCE NETWORKS FOR EFFECTIVE CUSTODIANS' PARTICIPATION IN THE SUSTAINABILITY OF LANGKAWI AS A GEOPARK}

In the case of Langkawi Geopark development, this article argues that governance networks play an important role in effective custodian participation for effective geopark governance. Before this article proceeds to explain governance networks between custodians, it will first define social network. What is social network? Why must custodians of Langkawi Geopark or anybody pay attention to networks? In simple terms, networks are about connectedness. They are ties or relationships between people or between organisations or between people and organisations. If they are ties between people, then they are called social ties or social relationships. In the case of Langkawi, social networks are social relationships between custodians. The author considers these networks as governance networks.

The custodians' governance networks in Langkawi Geopark are considered important simply because the ties between the custodians will enable an understanding of the need for their effective participation in the geopark. Their networks affect every aspect of their daily lives in Langkawi because networks surround them all the time exerting subtle and dramatic influence over their choices, actions, thoughts, feelings and desires relating to geopark participation (Christakis and Fowler, 2009: 7).

Several network theorists have put forth succinct and practical ideas and views about the significance of network in social everyday life. In the case of Langkawi geopark, the significance of governance networks for effective custodians' participation can be understood based on these ideas. Christakis and Fowler (2009: xiii) argue that if researchers link the scientific study of individuals to the study of groups, they are able to produce explanations about human experiences. Field (2003) echoes this argument. Thus, they share a common idea about basic network theory that individuals shape their networks, and at the same time, their networks shape and affect them. Individuals tend to establish ties or networks with people who share the same interests, histories, dreams, aspirations, views, ideas and others as them. This commonality or similarity idea underlies the key feature of a particular social network theory called homophily theory of networks.

According to homophily theory, similarities between individuals are important as that will determine who they want to connect and network with, who they want to influence, how to influence, who to learn from, how many ties and connections they want to create. Examples of similarities are views, ideas, values, norms, practises and action. Through their networks, those individuals will be able to determine how to achieve their goals, and to control how central they want to be in the social network. At the same time, the people whom they connect with (their 
network), with and whom they have similarities with will influence and affect how they think, what they do, how they feel, what they want, how to achieve their goals, what choices to choose, who to copy or learn from, and others.

In general, networks allow people to do more things and different things than they can do as individuals; it is like saying the whole is greater than the sum of its parts (Christakis and Fowler, 2009: 9). People connected into groups (networks) are able to do things that a disconnected collection of individuals cannot. Similarly, Field (2003: 1) opined that by making connections with one another, and keeping the connections going over time, people are able to work together to achieve things that they either could not achieve by themselves, or could only achieve with great difficulty. Hence, networks bring benefits to the connected people. However, networks can also be destructive.

The interest in studying social networks had started since the early 20th century and continued until today by anthropologists, sociologists, political scientists, mathematicians, economists, managers, administrators, medical practitioners, psychologists, criminologists and others. The study of social networks has paved the way to understand and explain various aspects of social and daily lives such as social interactions; social group unity; ethnic conflict; organisational behaviour and growth; work productivity, behaviour and motivation (Kapferer, 1972); managerial performance (Burt, 2010); spread of diseases; love and romance; deviance and criminal behaviour; friendship development and education issues (Kolleck, Haan and Fischbach, 2011). By systematically and academically analysing the nature and structure of social networks, researchers are able to delve into issues and offer solutions to problems concerning job seeking and recruitment; corporate elite power; work citation; community development; community participation; emotional contagion or spread of emotions; communication process; inter organisational relations; immigration patterns; work cooperation; marriage and family lives; personality development; business-politics relations and even gangsterism.

Several studies were conducted and reported by Chan (2004; 2005; 2007; 2008; 2009; 2015), Chan and Mohamad Zaki (2008), Chan, Halimaton Saadiah and Sarah (2011) and Chan et al. (2010; 2015) on social networks, focusing in Malaysia. Initially, Chan's utilisation of the network method led to her discovery of big business formation (patterning of the business group structure) in Malaysia that were based on formal organisational networks (i.e. interlocking directorships) established in conjunction with particular types of social networks such as friendship ties, ties to the state as ex-state bureaucrats and ties based on professional organisation memberships. The networks also indicated particular patterns of business-politics relations primarily evident at the top corporate sector in Malaysia. For Chan, social networks are a potential form of social capital. 
The process of Langkawi's development as a geopark has attracted the interest of Chan and her team of co-researchers to study the role of governance networks and social networks in the development process (Chan et al., 2010; 2015; Chan, Halimaton Saadiah and Sarah, 2011). These studies focus on social networks between individuals who are also custodians in Langkawi geopark development (see also Pumar (2005); and Kolleck, Haan and Fischbach (2011) for studies on social networks in sustainable development). The said study on social networks that spanned a period between 2013 and 2015 for the governance of Langkawi as a geopark had established that governance networks will become effective if there are shared values and norms among the networked custodians. This, in turn, will facilitate and guide their networks towards key shared norms such as influence, assistance and cooperation for geopark activities and projects.

The study team strongly agreed that theoretically, individuals who have established networks between them can work together towards geopark development through economically driven eco-tourism activities by demonstrating mutual behaviour depicting shared norms underpinned by particular shared values. Mutual influence, mutual assistance and cooperation are the shared norms discovered by the study team.

These shared norms are important to ensure and sustain participation in geopark related tourism and eco-tourism activities and projects. Loyalty and trust are the shared values. Other shared aspects between the custodians found to support the networks are, for instance, shared knowledge and understanding, emotions, experiences and viewpoints regarding the benefits of geopark to Langkawi; in addition to shared place of residence, i.e. village (see also Chan et al., 2015; 2016; Chan, 2015).

In the case of Langkawi Geopark, theoretically and in practice, effective custodian participation is best achieved through a proper governance network system whereby at least two or more organisational and non-organisational custodians establish networks between themselves irrespective of their social status, ethnicity, gender and wealth and income levels. Specifically, the custodians should, more than ever before, come together to work together and establish networks in a transparent, accountable, responsible, fair, trustworthy and consistent manner for the sake of good geopark governance (see UNPAGLOSSARY, n.d.; World Bank, 1991; United Nations Economic and Social Council, 2006 for definitions of governance). Effective participation for the custodians would be in terms of shared norms of behaviours such as cooperation, assistance and influence. Furthermore, such effective participation is based on shared views, shared values and some other shared norms guided to some extent by basic network principles such as reciprocity and mutuality. This implies that the custodians' social networks are shaped by shared values and shared norms. Similarity or commonality is a key 
feature in social networks formation of the custodians. Trust is also present as a network element.

As mentioned earlier, this article presents and discusses some findings from the two studies conducted by the author and her co-researchers on governance networks established in: (1) top down (or vertical) manner by a government development authority with several other local government authorities, NGOs and community members, and (2) horizontal manner between some community members from two villages who were actively engaging in eco-tourism in their villages at the time of the study. In brief, the main issue for the two studies is concerned with the effectiveness of governance networks that is based on shared views, shared values, norms, trust and other shared aspects for effective custodians' participation activities and projects and their sustainability. The objectives of the studies that produced the findings are:

1. To identify the custodians who cooperated in geopark activities and projects.

2. To trace the patterns and types of social networks between the custodians.

3. To ascertain types of shared norms and values that underlies the networks.

4. To determine other shared aspects between the custodians besides their shared values and norms.

\section{METHODOLOGY USED IN THE STUDY ON EFFECTIVE CUSTODIANS' PARTICIPATION}

The main units of analysis in both of the studies conducted by the author and her coresearchers are government authorities, NGO actors and community members in Langkawi. They are called "custodians" and also social network actors. Community members or villagers from two villages were selected for the studies based on their participation on eco-tourism activities linked to sustainable geopark development. They are Village A and Village B. All the actors' names are concealed for research ethical reasons, and pseudonyms have been assigned for each actor.

In social network analysis process, the actors are also known as "egos" or "nodes" while links or relationships between them are called "lines". Their linkages are depicted in network graphs. The following sections will further explain this.

A combination of qualitative and quantitative approaches guided by a combination of inductive-deductive-abductive-retroductive research strategies formed the research methodology of the studies. The studies began by being deductive when the researchers conducted a literature review to develop an initial set of behavioural indicators that imply shared values and shared norms relating to governance networks such as influence, assistance and cooperation among the 
custodians and various specific reasons for the norms to occur. To substantiate the key ideas on the indicators, the researchers applied ideas from a social network theory on shared values, shared norms and other shared aspects between social actors as shaping and developing social networks between them.

The development of the indicators was not conclusive at the early stage of the studies. Therefore, the researchers continued to pursue an inductive-abductive approach by conducting in-depth interviews during several pilot studies with several key informants from the government, relevant NGOs and communities. This is to obtain socially constructed meanings concerning values and norms seen and practised in geopark and geopark activities and projects, and custodian participation in geopark. This meaning seeking effort became part of the abductive research strategy. The studies finally turned retroductive when meanings on shared values and norms concerning geopark and custodian participation were utilised to fine-tune the indicators for use in the actual fieldwork. The fieldwork required informants to fill in a particular questionnaire that contained several matrix tables filled with the finalised indicators.

The main methods of data collection are documentary search as well as in-depth interviews and survey conducted during the fieldwork. As for the main method of data analysis, systematic content analysis and social network analysis were used.

Social network analysis is a method of analysis based on graph theory (Scott, 1991; Wasserman and Faust, 1994). This method traces and analyses pattern of networks in a qualitative and quantitative manner. This means social networks can be analysed and explained objectively in a numerical manner. The outcome of the analysis is represented by network graphs (or sociograms) that depict who is linked to who based on what, and how strong, weak or close are the relationships. In the studies by the author, the network patterns in the network graphs were based on shared values and shared norms that depict expected shared good behaviour (shared norms) in terms of influence, cooperation and assistance for effective participation in geopark activities, including activities related to ecotourism. Specifically, one of the studies examined various reasons for the norms to occur.

During the fieldwork, the informants were required to state any indicator in the questionnaire they deemed relevant. The information given by the informants was considered raw data. Upon completion of the fieldwork, the researchers inputted the raw questionnaire data into EXCEL files. Subsequently, the data was transferred into social network analysis software called UCINET 6 to analyse and determine qualitatively and quantitatively patterns of social networks based on shared values, shared norms and other shared aspects. UCINET 6 is able to analyse network patterns of single actors. This type of analysis called ego-centred network analysis was utilised in the studies. 
As mentioned earlier, network patterns of relationships are seen as lines in network graphs. The following sections of this article will visually portray those graphs. The graphs demonstrate the varying levels of strengths, weaknesses and closeness of relationships through varying thickness of the lines. The higher the number (or frequencies) of reasons for the norms to occur as well as the greater the sharing (or similarities) of values and other aspects the network actors have, the thicker the lines linking them and the stronger and closer the relationships. As will be seen in the following sections, the frequencies and kinds of similarities are represented in numbers. In empirical and practical terms, this implies that in order to participate effectively in geopark related activities through cooperation, assistance and influence, the actors established social networks between themselves based on shared values, shared norms and other shared aspects.

\section{RESEARCH FINDINGS}

The first section presents and discusses some findings of effective governance networks of a geopark activity entitled Geopark Carnival 2011. The following section will present some findings of effective ego-centred governance networks for the operation of eco-tourism activities conducted by local community members of two villages in Langkawi.

\section{Governance Networks for Custodians' Cooperation in Geopark Carnival 2011}

Geopark Carnival is an annual activity organised by a local government development authority in Langkawi. From 31 May until 4 June 2011, Geopark Carnival was carried out with the theme "Savouring the Nature, Nurturing the Culture". The meaning of this theme is the appreciation of the beauty of nature and cultivation of cultural heritage values in Langkawi. This theme suited the geopark concept as it embraced all elements of heritage conservation and sustainable development that are conveyed to the public and people of Langkawi.

Many government agencies, school authorities, hotel operators, business operators and retailers, NGOs and local communities were directly and actively involved in co-organising the carnival. Some of them did so because of work obligations while others carried out their corporate social responsibility or guided by volunteerism. The custodians identified are tagged as follow: Lad, Majpeba, Pejda, Japam, Podiram, Kema, Marim, Beliasu, and Tubacom. The NGOs were Latga, Lata, Kumperika, Fotoclu, Pasamal, Motoclas, Atiskeb, Wayaku, and Mahot, while Srigenda and Koleko were education organisations. Hotbellvist is the hotel operator while Azdaent is from the business sector. A local mosque was also involved. As mentioned earlier all the names are concealed for research ethical 
reasons. All the custodians worked together in various stages of the activity; from decision making to planning and implementation. The level of cooperation was generally good. All the custodians developed a series of working relationships and networked cordially among themselves especially with LADA.

Shared aspects, as noted before, allowed the custodians to work together, cooperate and consequently bind their work networks. The shared aspects are shared understanding, knowledge and viewpoints concerning geopark and the importance of geopark to Langkawi in terms of socio-economic development, heritage conservation and sustainable development. Interviews and observations showed that there was trust between the custodians. Figure 1 shows the finding on the patterns of governance networks based on those shared aspects.

Figure 2 further shows network patterns based on shared values and shared norms for cooperation among the custodians that ensured the implementation of the carnival. The common and shared norms of behaviour demonstrated were constant communications, efforts to understand information and messages conveyed by the main organiser, efforts to constantly refer to the main organiser in case of doubts or queries and compliance to work rules imposed by the main organiser. In addition, the custodian gave moral support to one another. Shared value like trust was evident.

\section{Governance Networks for Local Community Custodians' in Eco-tourism Activity}

This section briefly discusses findings from another study conducted by the study team on social networks for community participation in a geopark eco-tourism related activity in Langkawi. Boat operations for eco-tourism were the activities focused in the study. Interesting patterns of shared values, shared norms and other shared aspects that underpinned governance networks (i.e. social networks) were unveiled among members of local communities from Village A and Village B. Various specific reasons for the norms to occur were also uncovered.

At the time of the study, the residents were actively involved in ecotourism activities in their villages in Langkawi. The local community members were network actors who participated in the eco-tourism activity as tourist boat operators, boat owners or boat operators employed by the boat owners. In Village A, a total of 22 network actors were identified while 26 networks actors were identified in Village B.

Key shared values identified were trust and loyalty while other shared aspects were knowledge (cognition), emotion, viewpoints, experiences and place of residences. Most of these actors were friends, relatives, neighbours, employers and employees. Therefore, the types of social networks were friendship networks, family ties, neighbour networks and work ties. These types of networks have been 


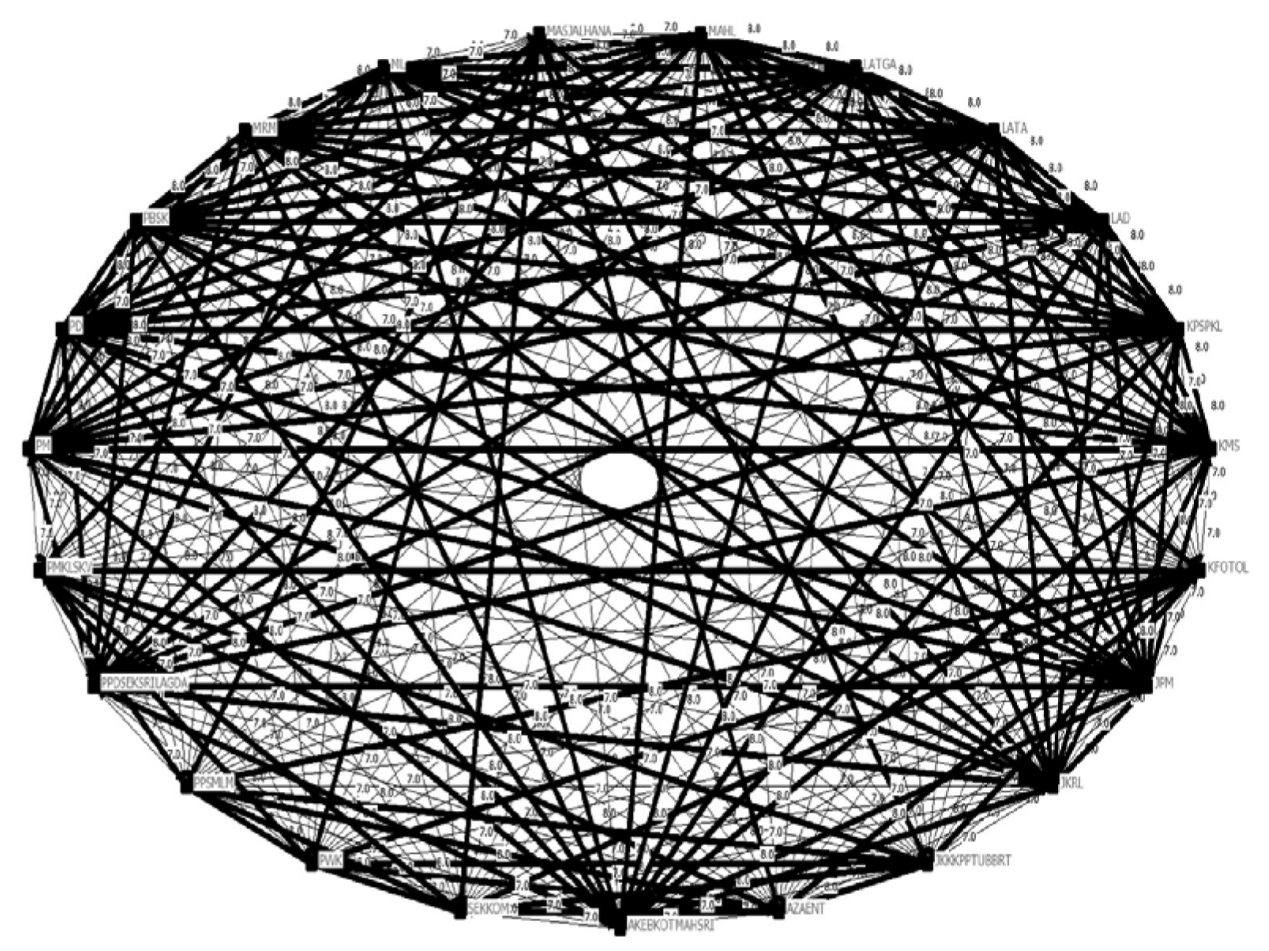

Legends

Thin lines represent links between actors (i.e. social relationships or social networks) - lines developed from particular number of similarities (shared understanding and awareness for cooperation between custodians in Geopark Carnival) between those actors.

Thick lines represent links between actors (i.e. social relationships or social networks) - lines developed from particular number of similarities (shared understanding and awareness for cooperation between custodians in Geopark Carnival) between those actors.

Numbers on lines - mean number of similarities (shared understanding and awareness - for cooperation between custodians in Geopark Carnival) between actors that developed their social networks.

Nodes represent network actors who have been linked through the social networks by various kinds of similarities (shared understanding and awareness for cooperation between custodians in Geopark Carnival) between them.

Figure 1: Network graph on shared understanding and awareness for cooperation among custodians in Geopark Carnival, 2011. 


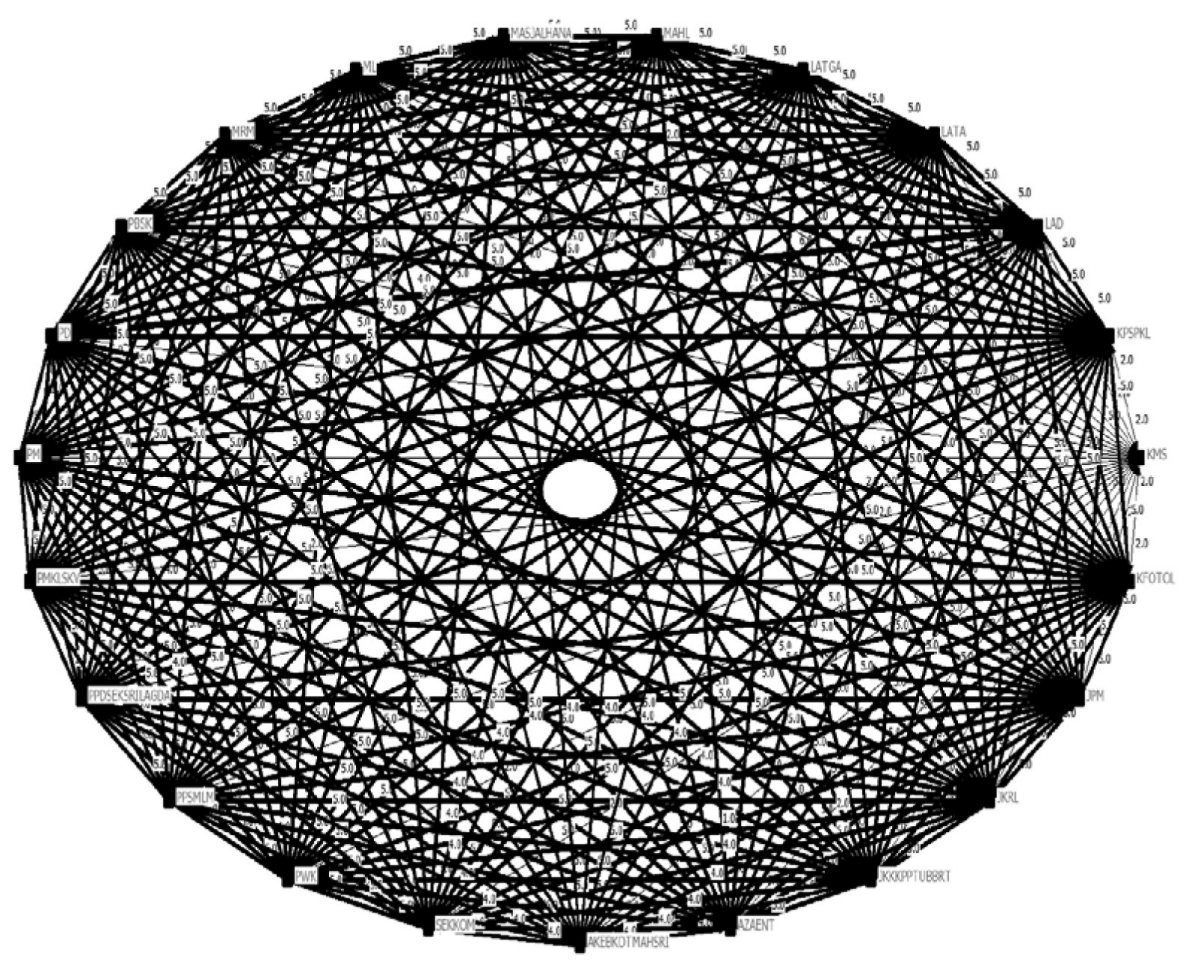

Legends

Thin lines represent links between actors (i.e. social relationships or social networks) - lines developed from particular number of similarities (shared value and norms for cooperation between custodians in Geopark Carnival) between those actors.

Thick lines represent links between actors (i.e. social relationships or social networks) - lines developed from particular number of similarities (shared value and norms for cooperation between custodians in Geopark Carnival) between those actors

Numbers on lines - mean number of similarities (shared value and norms for - cooperation between custodians in Geopark Carnival) between actors that developed their social networks.

Nodes represent network actors who have been linked through the social networks by various kinds of similarities (shared value and norms for cooperation between custodians in Geopark Carnival) between them.

Figure 2: Network graph on shared values and norms for cooperation among custodians as a basis of governance networks in Geopark Carnival 2011. 
established prior to their participation in the eco-tourism activity. Some networks were pre-existing and familial in nature. The shared values and other shared aspects acted as a foundation for shared norms.

This means that the actors demonstrated similar behaviour such as giving influence, assistance and cooperation as a way of showing their participation in the eco-tourism activities. There were various reasons for the shared behaviour or norms to occur. Among the reasons identified were generation of revenue, increase in family socio-economic status, increase in village's socio-economic status, new work opportunities, heritage conservation, benefits for future generation, economic development of the village, tourist promotion, assistance to friends and family members, promotion of villages to tourists, boat operator replacement, similar community association membership, similar work, effort in promoting boat operation to tourists, and expertise in boat operation. The shared values and norms actually reinforced existing and pre-existing social networks.

\section{Examples of social network graphs depicting shared norms of influence, assistance and cooperation among network actors in Village A and Village $B$}

This section firstly demonstrates some examples of network graphs of influence of network actors in Village A and Village B. Figures 3-10 that follow show network graphs of assistance and cooperation among the same network actors in both villages. In the graphs, the varying thickness of the lines linking the actors represents varying types of shared values and shared norms of influence, assistance and cooperation among the actors in both villages, and varying reasons for the norms to occur. The thicker the lines, the higher the numbers (or frequencies) of reasons for cooperation, influence and assistance to occur as well as the more similarities the actors share, and the stronger their social networks for participation in ecotourism activities in the villages through influence, assistance and cooperation.

\section{Some examples of other shared aspects among network actors in Village A and Village $B$}

This section presents and discusses some findings of other shared aspects among the network actors from both Village A and Village B, in addition to other shared norms and values that have been discussed in the earlier section of this article. The shared aspects are:

1. Perceptions concerning benefits of participation in eco-tourism activities and geopark

2. Cognitive i.e. knowledge about Langkawi as a geopark

3. Experiences in eco-tourism activities

4. Neighbourhood, i.e. place of residence in the same village 


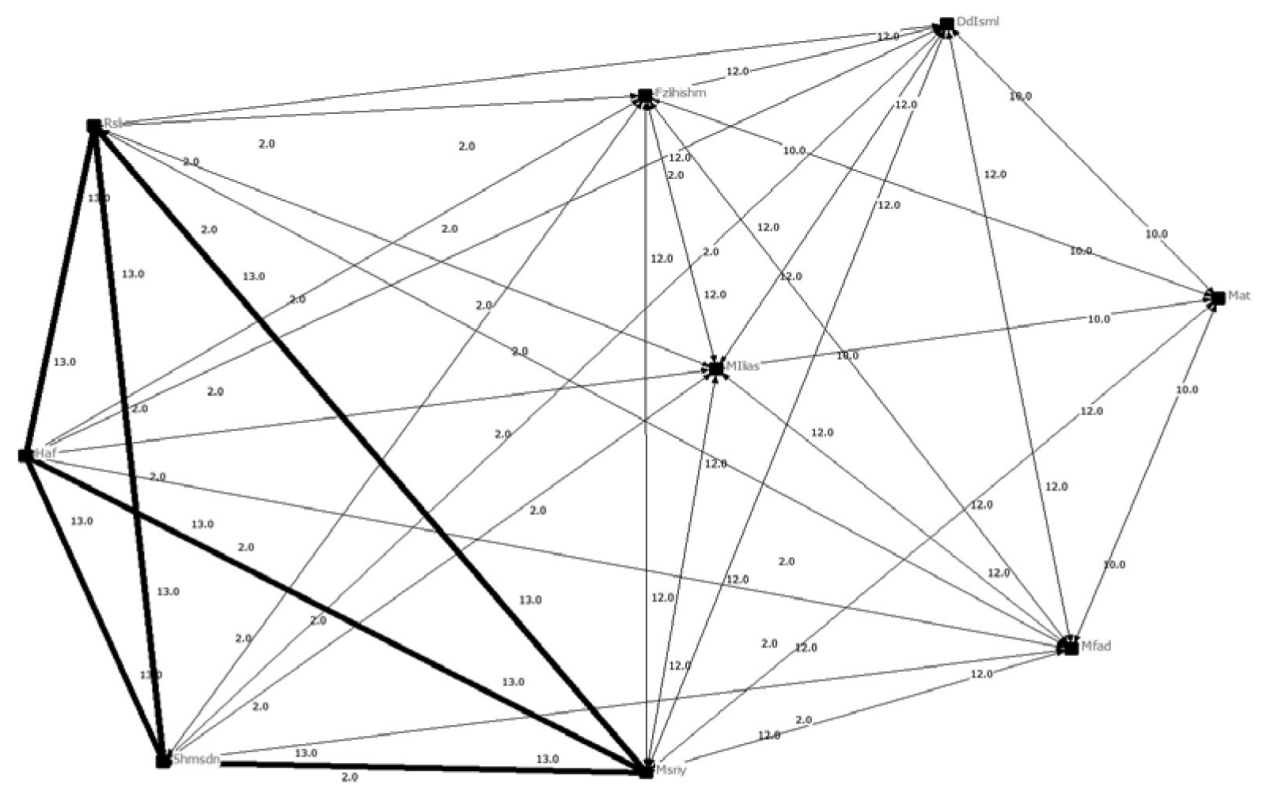

\section{Legends}

Thin lines represent links between actors (i.e. social relationships or social networks) - lines developed from particular numbers of reasons and other similarities for influence to occur between those actors.

Thick lines represent links between actors (i.e. social relationships or social networks) - lines developed from particular numbers of reasons and other similarities for influence to occur between those actors.

Numbers on lines - mean particular numbers of reasons and other similarities for influence to occur between actors that developed their social networks.

Nodes represent network actors who have been linked through the social networks by particular numbers of reasons and other similarities for influence to occur between those actors.

Figure 3: Social networks of influence of actor Msriy in Village A. 


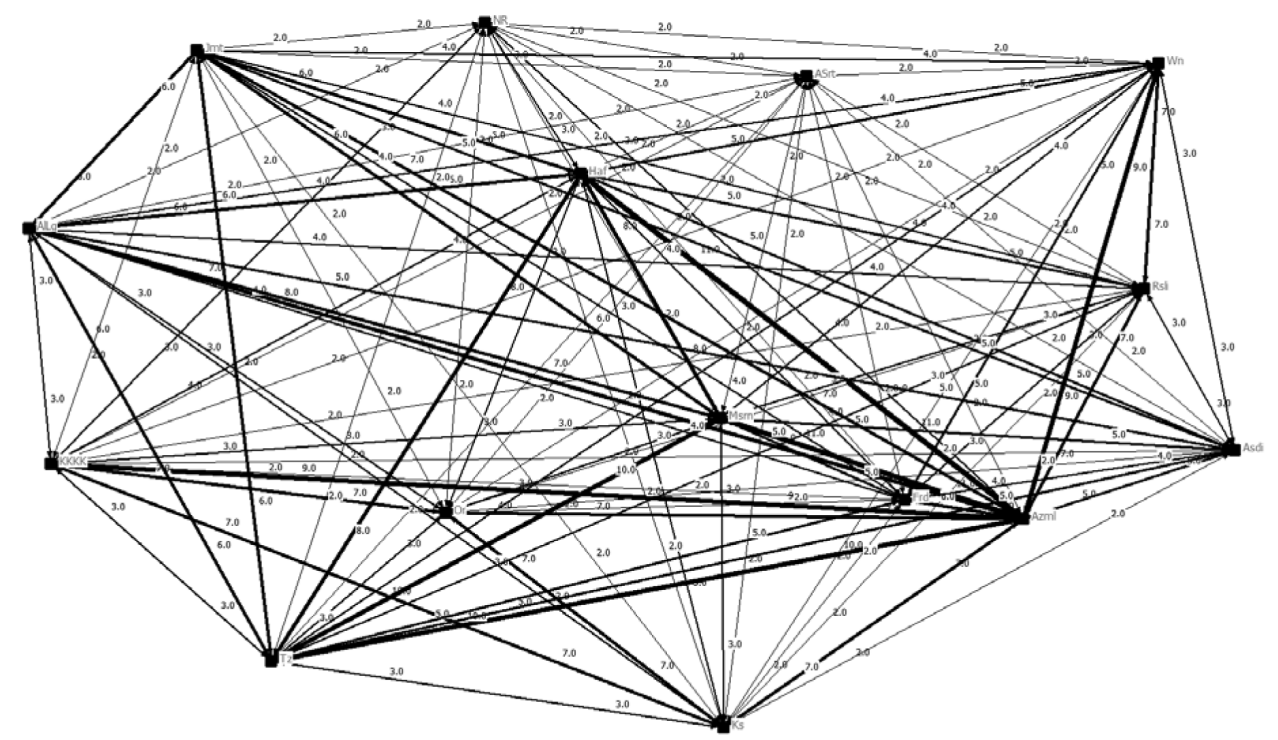

Legends

Thin lines represent links between actors (i.e. social relationships or social networks) - lines developed from particular numbers of reasons and other similarities for influence to occur between those actors.

Thick lines represent links between actors (i.e. social relationships or social networks) - lines developed from particular numbers of reasons and other similarities for influence to occur between those actors.

Numbers on lines - mean particular numbers of reasons and other similarities for influence to occur between those actors that developed their networks.

Nodes represent network actors who have been linked through the social networks by particular numbers of reasons and other similarities for influence to occur between them.

Figure 4: Social networks of influence of actor Azml in Village A. 


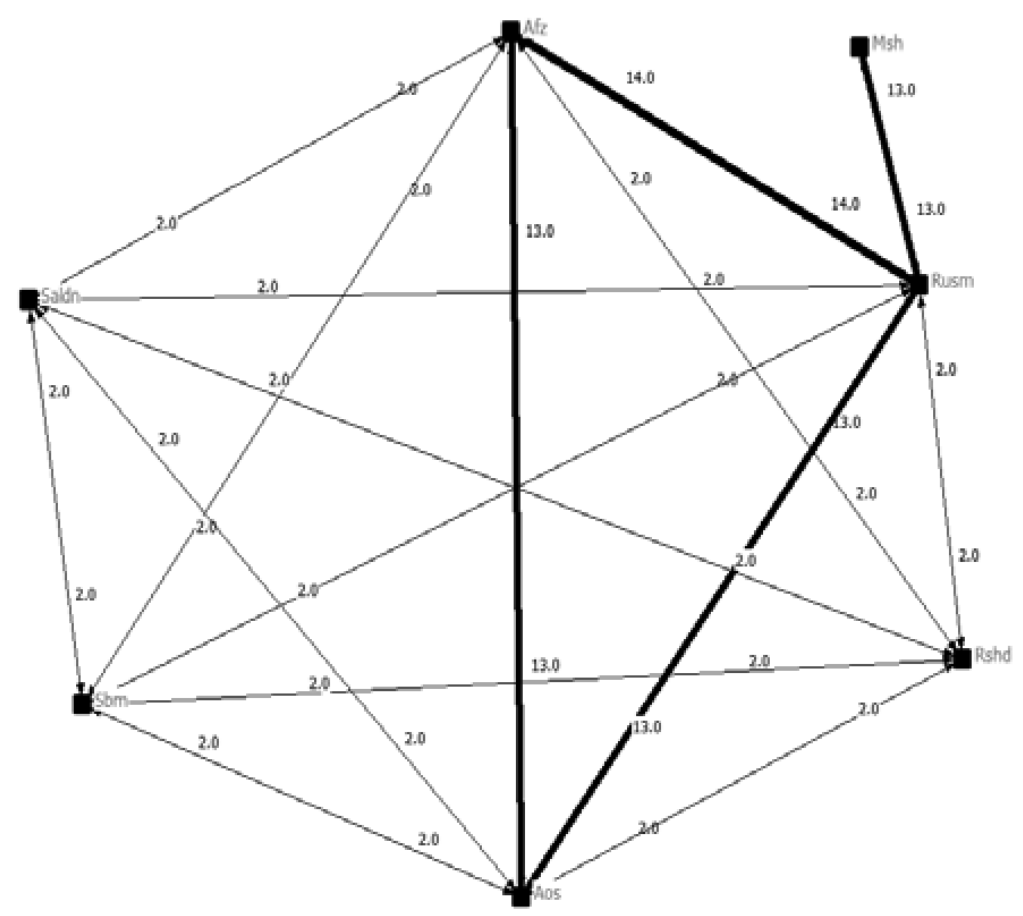

\section{Legends}

Thin lines represent links between actors (i.e. social relationships or social networks) - lines developed from particular numbers of reasons and other similarities for influence to occur between those actors.

Thick lines represent links between actors (i.e. social relationships or social networks) - lines developed from particular numbers of reasons and other similarities for influence to occur between those actors.

Numbers on lines - mean particular numbers of reasons and other similarities for influence to occur between those actors that developed their social networks.

Nodes represent network actors who have been linked through the social networks by particular numbers of reasons and other similarities for influence to occur between those actors.

Figure 5: Social networks of influence of actor Rusm in Village B. 


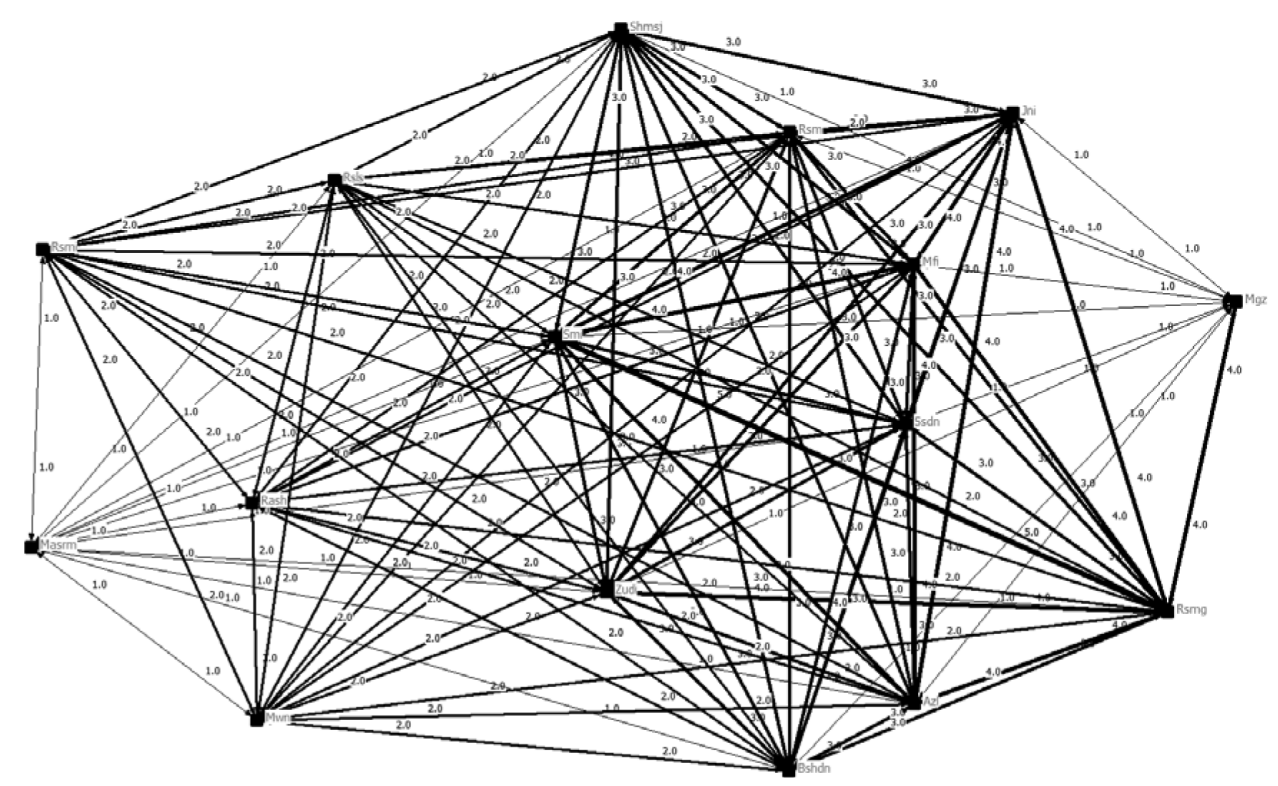

\section{Legends}

Thin lines represent links between actors (i.e. social relationships or social networks) - lines developed from particular numbers of reasons and other similarities for influence to occur between those actors.

Thick lines represent links between actors (i.e. social relationships or social networks) - lines developed from particular numbers of reasons and other similarities for influence to occur between those actors.

Numbers on lines - mean particular numbers of reasons and other similarities for influence to occur between those actors that developed their social networks.

Nodes represent network actors who have been linked through the social networks by particular numbers of reasons and other similarities for influence to occur between those actors.

Figure 6: Social networks of influence of actor Rsmg in Village B. 


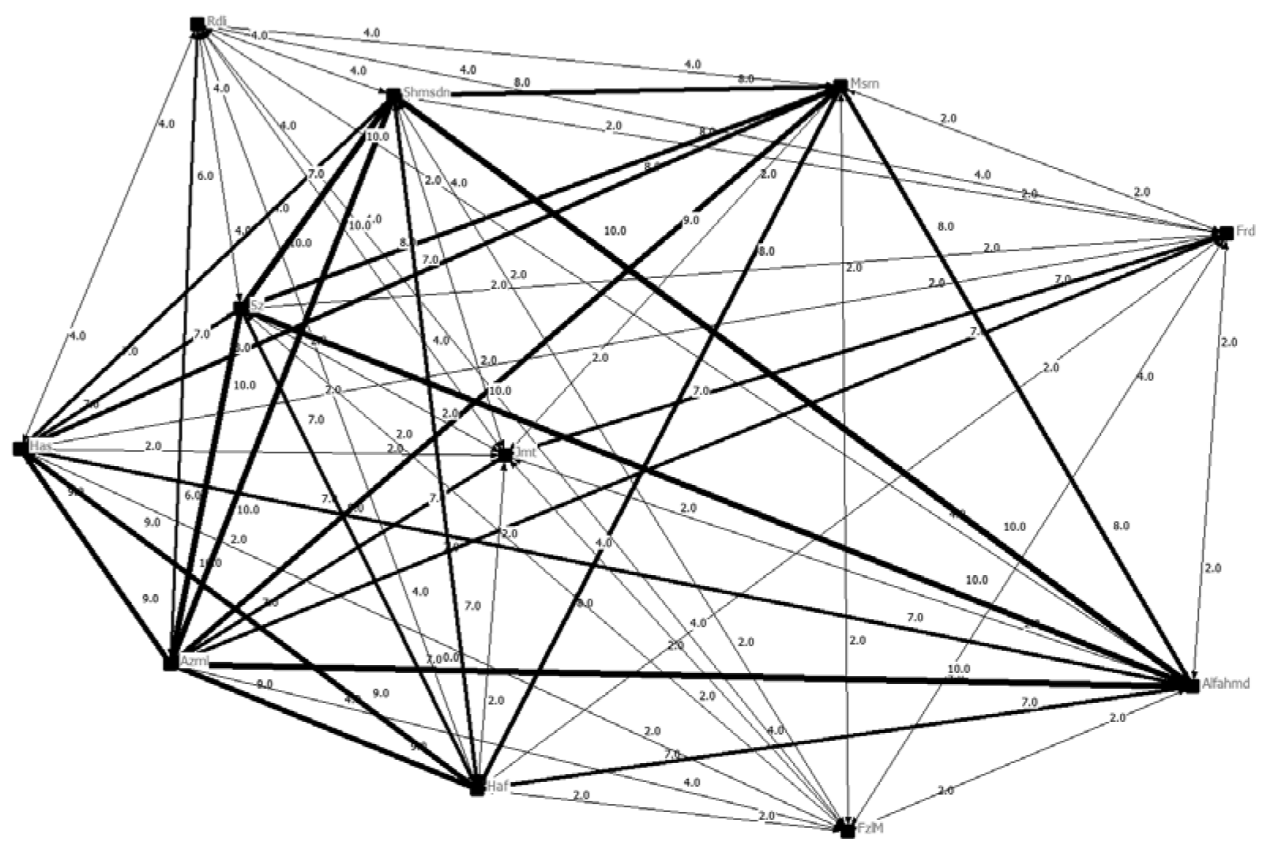

Legends

Thin lines represent links between actors (i.e. social relationships or social networks) - lines developed from particular numbers of reasons and other similarities for assistance and cooperation to occur between those actors.

Thick lines represent links between actors (i.e. social relationships or social networks) - lines developed from particular numbers of reasons and other similarities for assistance and cooperation to occur between those actors.

Numbers on lines - mean particular numbers of reasons and other similarities for - assistance and cooperation to occur between those actors that developed their social networks.

Nodes represent network actors who have been linked through the social networks by particular numbers of reasons and other similarities for assistance and cooperation to occur between those actors.

Figure 7: Social networks of assistance and cooperation of actor Azml in Village A. 


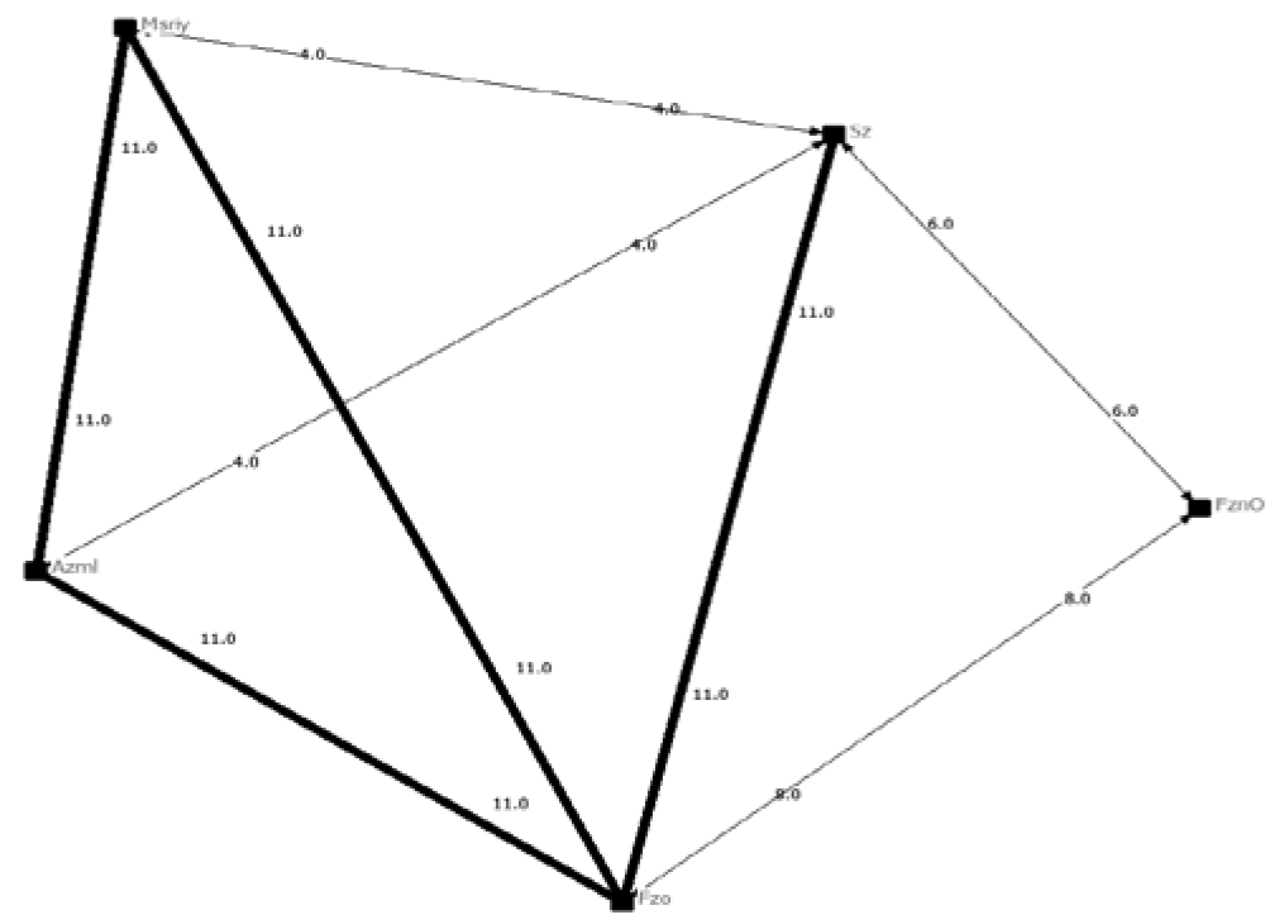

\section{Legends}

Thin lines represent links between actors (i.e. social relationships or social networks) - lines developed from particular numbers of reasons and other similarities for assistance and cooperation to occur between those actors.

Thick lines represent links between actors (i.e. social relationships or social networks) - lines developed from particular numbers of reasons and other similarities for assistance and cooperation to occur between those actors.

Numbers on lines - mean particular numbers of reasons and other similarities for

- assistance and cooperation to occur between those actors that developed their social networks.

Nodes represent network actors who have been linked through the social networks by particular numbers of reasons and other similarities for assistance and cooperation to occur between those actors.

Figure 8: Social networks of assistance and cooperation of actor Fzo in Village A. 


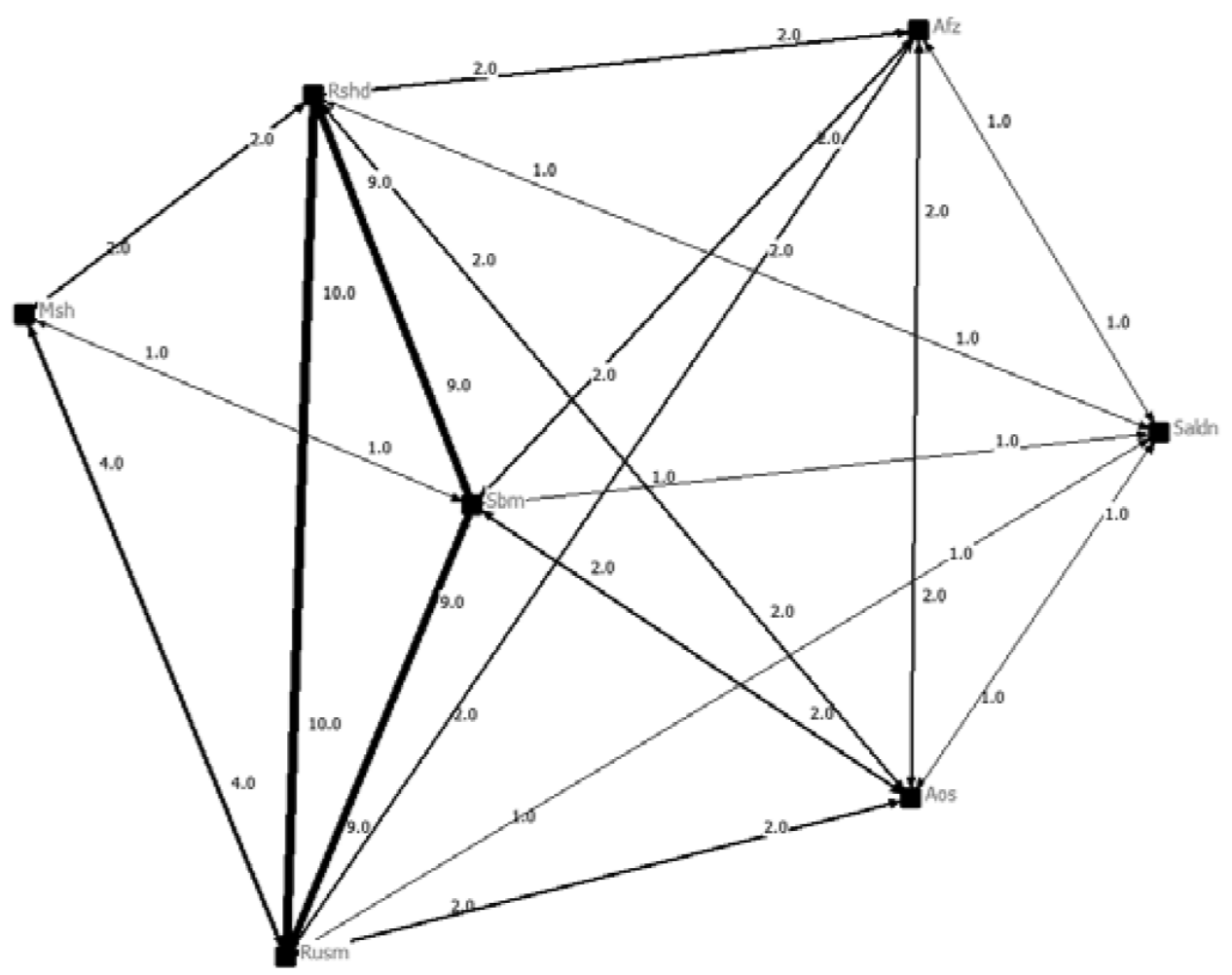

\section{Legends}

Thin lines represent links between actors (i.e. social relationships or social networks) - lines developed from particular numbers of reasons and other similarities for assistance and cooperation to occur between those actors.

Thick lines represent links between actors (i.e. social relationships or social networks) - lines developed from particular numbers of reasons and other similarities for assistance and cooperation between those actors.

Numbers on lines - mean particular numbers of reasons and other similarities for assistance and cooperation between those actors that developed their social networks.

Nodes represent network actors who have been linked through the social networks by particular numbers of reasons and other similarities for assistance and cooperation between those actors.

Figure 9: Social networks of assistance and cooperation of actor Rusm in Village B. 


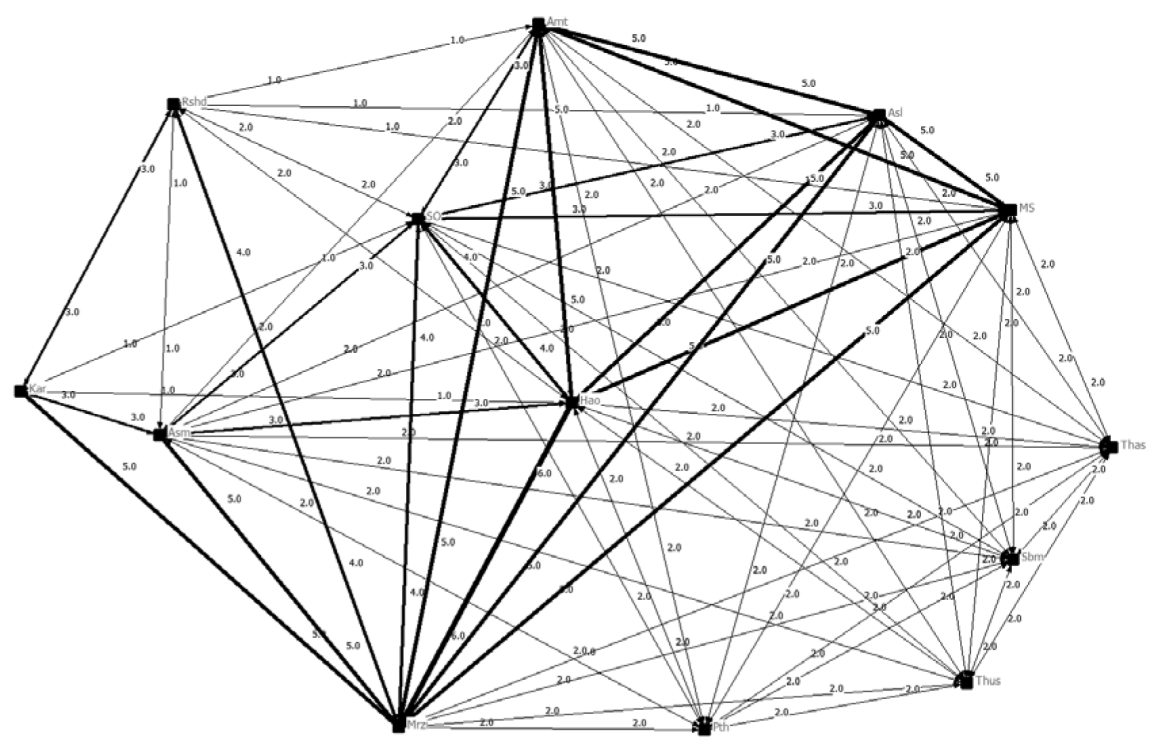

Legends

Thin lines represent links between actors (i.e. social relationships or social networks) - lines developed from particular numbers of reasons and other similarities for assistance and cooperation to occur between those actors.

Thick lines represent links between actors (i.e. social relationships or social networks) - lines developed from particular numbers of reasons and other similarities for assistance and cooperation to occur between those actors.

Numbers on lines - mean particular numbers of reasons and other similarities for - assistance and cooperation to occur between actors that developed their social networks.

Nodes represent network actors who have been linked through the social networks by particular numbers of reasons and other similarities for assistance and cooperation to occur between those actors.

Figure 10: Social networks of assistance and cooperation of actor Mrzi in Village B.

The actors similarly perceived various benefits concerning participation in eco-tourism activities and geopark, and they also shared all kinds of knowledge about Langkawi as a geopark. Some benefits perceived were exchange of ideas and knowledge, village gaining benefits, new work opportunities, village socioeconomic growth, enhanced community relationships, tourist attractions and assisting friends and family in the activities. Concerning knowledge of Langkawi as a geopark, some actors had knowledge of geopark as consisting of 99 islands, 
ecological conservation, cultural conservation, biological conservation, place filled with rocks, geopark for tourist attraction, geopark as a place for new work opportunities, geopark for socio-economic development and others.

The following Figure 11 depicts shared perceptions on various benefits of participation in eco-tourism activities and geopark and shared knowledge about Langkawi as a geopark. For practical purpose, this article shall only visually present some examples of graphs for Village B. Although not presented visually in this article, the network graphs on Village A also have almost similar graphs designs, with many nodes and lines and strength of lines represented by numbers.

As shown, Figure 11 from the case of Village B depicts the varying thickness of the lines linking the actors representing varying types of shared perceptions and shared knowledge in the village. This finding is similar for Village A. The thicker the lines, the more similarities were found among the actors. This finding implies that all the 26 actors in Village B had established close and strong networks based on shared perceptions of benefits of eco-tourism participation and geopark as well as based on shared knowledge about Langkawi as a geopark. Hence, they were also able to influence and assist one another and cooperate well in the geopark activities based on those similarities.

Shared experiences in eco-tourism activities and shared place of residence, i.e. neighbourhood

Shared experiences between the villagers referred to their experiences in participation in eco-tourism activities, whether in ownership of boats for operations or boat operations. Most of the actors were boat operators while some were employers of the operators. All the actors in both villages were living in the same neighbourhoods or villages at the time of the study.

\section{Types of social networks}

There are two types of social networks uncovered among the network actors in the Geopark Carnival and the two villages, i.e. formal and informal ones. The formal one is based on employer-employee relations while the informal ones are based on:

1. Friendship networks

2. Family ties based on marriage

3. Family ties

4. Work ties

5. Neighbourhood ties 


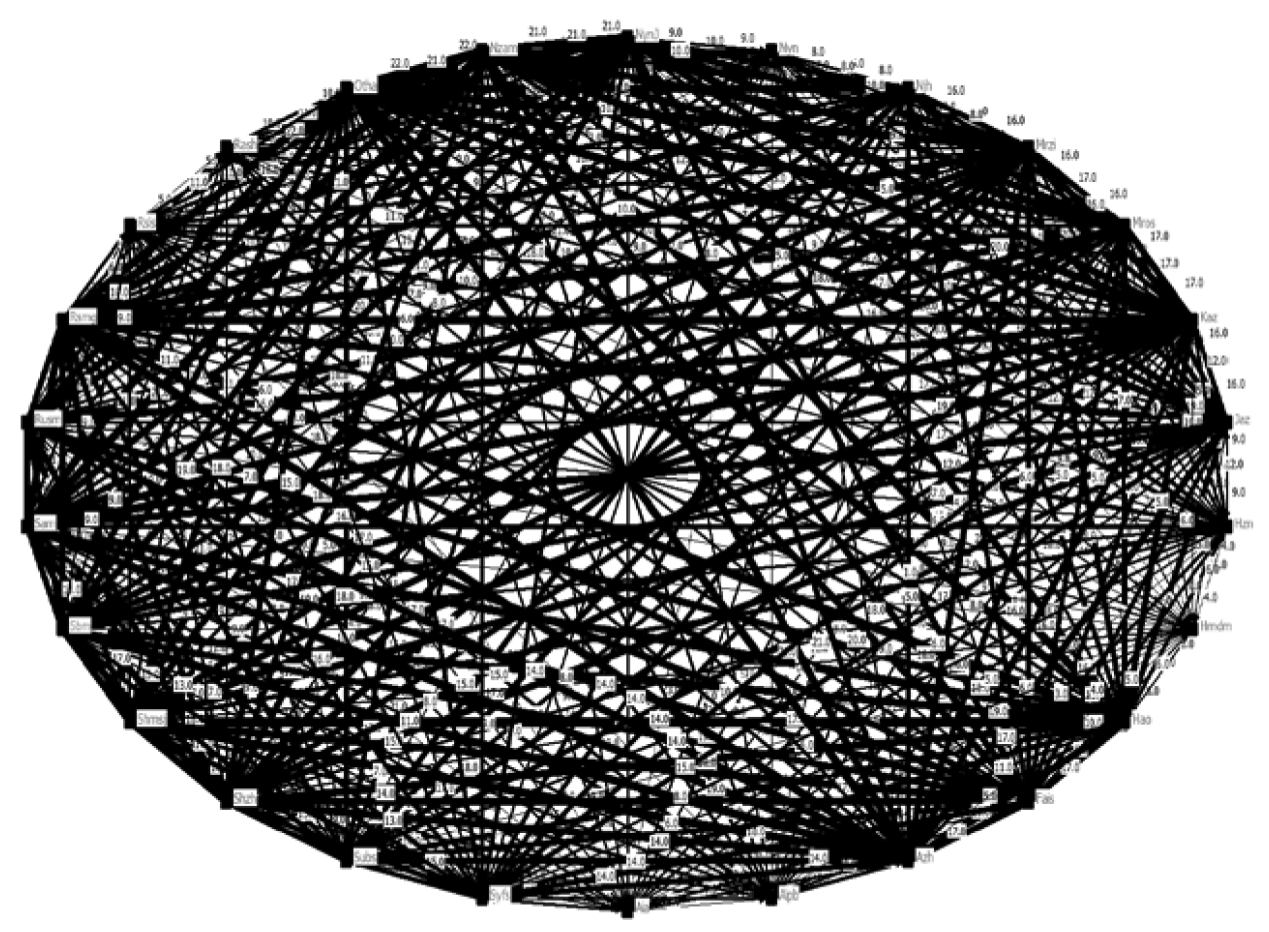

Legends

Thin lines represent links between actors (i.e. social relationships or social networks) - lines developed from particular numbers of similarities (shared perceptions of benefits of eco-tourism participation and geopark) between those actors.

Thick lines represent links between actors (i.e. social relationships or social networks) - lines developed from particular numbers of similarities (shared perceptions of benefits of eco-tourism participation and geopark) between those actors.

Numbers on lines - mean numbers of similarities (shared perceptions of benefits - of eco-tourism participation and geopark) between actors that developed their social networks.

Nodes represent network actors who have been linked through the social networks by various kinds of similarities (shared perceptions of benefits of eco-tourism participation and geopark) between them.

Figure 11: Social networks of shared perceptions of benefits of eco-tourism participation and geopark among actors in Village B. 


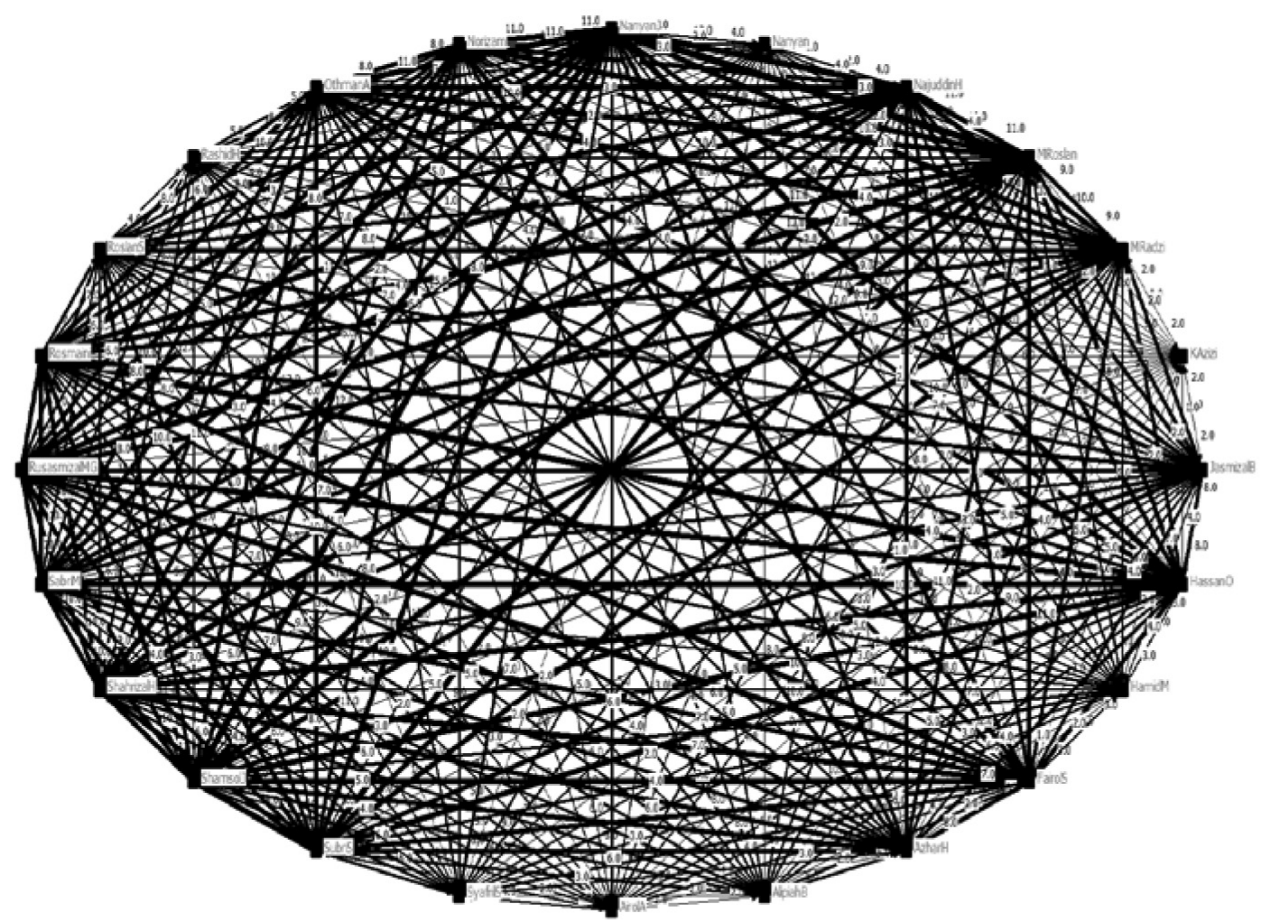

Legends

Thin lines represent links between actors (i.e. social relationships or social networks) - lines developed from particular numbers of similarities (shared knowledge) between those actors.

Thick lines represent links between actors (i.e. social relationships or social networks) - lines developed from particular numbers of similarities (shared knowledge) between those actors.

- Numbers on lines - mean numbers of similarities (shared knowledge) between actors that developed their social networks.

Nodes represent network actors who have been linked through the social networks by various kinds of similarities (shared knowledge) between them.

Figure 12: Social networks of shared knowledge about Langkawi as a geopark among actors in Village B. 
Overall, all the above findings demonstrate that geopark related activities in Langkawi, i.e. Geopark Carnival and boat operations for mangrove tourist visits in Village A and Village B, were able to succeed because the social networks, that linked the actors who were involved in the activities, were supported by various commonalities found between them. The commonalities were shared values, shared norms and other shared aspects such as knowledge (cognition), emotion, viewpoints, experiences and place of residence. These commonalities linked the actors who were friends, relatives, neighbours, employers or employees with one another. The shared values and other shared aspects indeed became a foundation for the formation of social networks that eventually enabled the actors to establish shared norms such as giving influence, assistance and cooperation as a way of showing their participation in the eco-tourism activities.

In the case of the Geopark Carnival, the government and nongovernmental actors together with some community members shared the values of trust, understanding, knowledge and viewpoints concerning geopark and the importance of geopark to Langkawi in terms of socio-economic development, heritage conservation and sustainable development. As for Village A and Village B, among the reasons for the shared behaviour or norms to occur were the generation of revenue, increase in family socio-economic status, increase in village's socioeconomic status, new work opportunities, heritage conservation, benefits for future generation, economic development of the village, tourist promotion, assistance to friends and family members, promotion of villages to tourists, boat operator replacement, similar community association membership, similar work, efforts in promoting boat operation to tourists, and expertise in boat operation.

\section{CONCLUSION}

This article confirms that governance networks are important elements in understanding the nature of custodians' participation in the sustainability of Langkawi as a geopark, especially their effective participation in ensuring their continuous operation of geopark related activities. The custodians were government authorities, non-government authorities, private business sector and local community members. The governance networks were found to have been developed from both top-down and bottom up manner in the development of Langkawi as a geopark, mainly through tourism and eco-tourism activities. Governance networks require shared views, knowledge and understanding, trust, and shared values and shared norms among custodians to make them work, and more importantly to make the networks work well.

Shared values such as trust and loyalty, while shared norms such as shared behaviours are generally considered as good and proper behaviour for 
the custodians' effective participation in geopark development based on heritage conservation and sustainable development in Langkawi. The key behaviours were influence, assistance and cooperation and they were guided by the shared values. There are also other types of shared norms of behaviours as discussed earlier.

What is also clear is that similarities, that is, shared values and norms, between the custodians could facilitate mutual influence as well as support. Theoretically and practically, without these values and norms, governance networks or any networks for that matter, might not work well or effectively, including existing and pre-existing ones such as family ties, friendship ties, work relationships and neighbourhood ties.

\section{ACKNOWLEDGEMENTS}

Acknowledgements are given to the Ministry of Higher Learning (KPT) and UKM for funding the research projects under research grants XX-01-2011 and FRGS/1/2013/SS03/UKM/02/4 respectively that have produced findings and analysis for this article. The author also expresses her deep gratitude and appreciation to her co-researchers from both projects for their contributions.

\section{REFERENCES}

Burt, R. S. 2010. Neighbor networks: Competitive advantage local and personal. Oxford: Oxford University Press.

Caspersen, O. H. 2009. Public participation in strengthening cultural heritage: The role of landscape character assessment in Denmark. Geografisk Tidsskrift-Danish Journal of Geography 109(1): 33-45. https://doi.org/10.1080/00167223.2009.1 0649594

Carson, D. and J. Macbeth, eds. 2005. Regional tourism cases: Innovation in regional tourism. Australia: Common Ground Publishing. http://sustain.pata.org/wpcontent/uploads/2015/02/FINAL_REGIONAL-Tourism-Cases.pdf (accessed 24 August 2012).

Chan Kim Ling@ Geraldine. 2015. Social networks as social capital for eco-tourism in Langkawi Geopark: A preliminary sociological study. Geografia Online (Malaysian Journal of Society and Space) 11(13): 156-164.

2009. Social capital and social networks in the Malaysian corporate elite world: A conceptual framework. Jurnal E-Bangi 4(1): 30-45.

2008. Jaringan elit korporat dan cabaran sosio-budaya di Malaysia: Senario pada awal dan pertengahan 1990an. In Transformasi masyarakat Malaysia: Cabaran famili, gender dan sosiobudaya, ed. Rahimah Abdul Aziz, 180-216. Bangi: Penerbit UKM. 
2007. Mengkonseptualisasi modal sosial dan pengorganisasian elit korporat Malaysia: Satu kes untuk memahami Indonesia? In Indonesia dan Malaysia dalam era globalisasi dan lokalisasi: Mewujudkan kemakmuran bersama, Vol 1, eds. Armida S. Alisjahbana, Ramdan Panigoro, Parikesit, Abd Hair Awang, Chan Kim Ling@Geraldine, Junaenah Sulehan, Nik Hairi Omar, Shaiful Bahri Md. Radzi, Ruzy Suliza Hashim and Zarina Othman. Bandung: Universitas Padjadjaran.

2005. Social organisation of the business elite and big business growth: Malaysia during the 1990s economic boom. Akademika 65(1): 69-90.

2004. Business-politics relations in Malaysia: A sociological analysis of interlocking directorships. Ph.D. diss., London School of Economics and Political Science.

Chan, K. L. Geraldine, S. Selvadurai, Rahimah Abdul Aziz and Afiqah Norizan. 2016. Building a social network model for effective stakeholders' participation and cooperation in heritage conservation and sustainable development in Langkawi, Geopark. Research report. FRGS/1/2013/SS03/UKM/02/4.

Chan, K. L. Geraldine, Abdul Hadi Harmans Shah, S. Selvadurai, Rahimah Abdul Aziz and Afiqah Norizan. 2015. Social networks and sustainability in Langkawi Geopark. In Civilization, hopes and discontent: Insights from the social sciences and humanities, 65-85. Bangi: Fakulti Sains Sosial dan Kemanusiaan.

Chan, K. L. Geraldine, Halimaton Saadiah Hashim and Sarah Aziz. 2011. Introducing network planning: An example from Langkawi. Planning Malaysia (Journal of the Malaysia Institute of Planning) 1(Special issue): 159-184.

Chan, K. L. Geraldine, Sarah Aziz, Halimaton Saadiah Hashim and Rahimah Abdul Aziz. 2010. Sistem jaringan governans untuk Langkawi Geopark: Pengkisahan konseptual. Akademika 80: 69-84.

Chan, G. and Mohamad Zaki Ibrahim. 2008. Conceptualising network society in Malaysia. Asian Journal of Social Science 36(5): 773-791. https://doi. org/10.1163/156853108X364226.

Christakis, N. A. and J. H. Fowler. 2009. Connected: The surprising power of our social networks and how they shape our lives. New York: Little, Brown and Company.

Cooper, C., N. Scott, R. March, I. Wilkinson, C. Pforr and G. Thompson. 2006. The network structure of tourism operators in three regions of Australia. Australia: CRC for Sustainable Tourism Pty Ltd. http://sustain.pata.org/wp-content/uploads/2014/12/ Cooper_NetwrkTourismOps.pdf (accessed 17 November 2017).

Dale, A., C. Ling and L. Newman. 2010. Community vitality: The role of community-level resilience adaption and innovation in sustainable development. http://www.mdpi. com/2071-1050/2/1/215 (accessed 17 September 2013).

Drexhage, J. and D. Murphy. 2010. Sustainable development: From Bruntland to Rio 2012. Background paper: Prepared for the consideration by the High Level Panel on Global Sustainability at its first meeting, 19 September. http://www. surdurulebilirkalkinma.gov.tr/wp-content/uploads/2016/06/Background_on_ Sustainable_Development.pdf (accessed 25 April 2017).

Few, R. n.d. Containment and counter-containment: Planner/community relations in conservation planning. The Geographical Journal 167(2): 111-124. https://doi. org/10.1111/1475-4959.00011. 
Field, J. 2003. Social capital. London: Routledge.

Global Geoparks Network. n.d. What is a UNESCO global geopark? http://www. globalgeopark.org/aboutGGN/6398.htm (accessed 17 November 2017).

Granovetter, M. 1985. Economic action and social structure: The problem of embeddedness. American Journal of Sociology 91(3): 481-510. https://doi.org/10.1086/228311. 1973. The strength of weak ties. American Journal of Sociology 78: 1360-1380. https://doi.org/10.1086/225469.

Hampton, M. P. 2004. Heritage, local communities and economic development. Annals of Tourism Research 32(3): 735-759. https://doi.org/10.1016/j.annals.2004.10.010

Hanberger, A. 2011. Evaluation of local sustainable development - approaches and use. In Evaluation for participation and sustainability in planning, eds. A. Hull, E. R. Alexander, A. Khakee and J. Woltjer. Oxon: OX: Routledge.

Kapferer, B. 1972. Strategy and transaction in an African factory: African workers and Indian management in a Zambian town. Manchester: Manchester University Press.

Khan, S. 2009. Sustainable development and community participation: A case study of Great Limpopo Transfrontier Park. http://www.iese.ac.mz/lib/publication/II conf/CP31_2009_Khan.pdf(accessed 17 September 2013).

Kolleck, N., G. de Haan and R. Fischbach. 2011. Social networks for path creation: Education for sustainable development matters. Journal of Futures Studies 15(4): 77-92. http://www.jfs.tku.edu.tw/15-4/A06.pdf (accessed 1 November 2012).

Leeuwis, C. 2000. Reconceptualizing participation for sustainable rural development: Towards a negotiation approach. Development and Change 31: 931-959. https://doi.org/10.1111/1467-7660.00184.

Lourenço, N., C. R. Machado, M. do Rosário Jorge and L. Rodrigues. n.d. Sustainability: Importance of social networks in the decision-making processes. Working paper.

Monno, V. and A. Khakee. 2011. More of the same or just right and robust? Evaluating participatory planning. In Evaluation for participation and sustainability in planning, eds. A. Hull, E. R. Alexander, A. Khakee and J. Woltjer. Oxon: OX: Routledge.

Morris, J. n.d. Removing the barriers to community participation. A report by The National Community Forum, UK.

National Marine Sanctuaries. n. d. Custodian participation Module 5. http://sanctuaries. noaa.gov/management/pdfs/Day5-CUSTODIANS-MANUAL.2.pdf (accessed 24 August 2012).

Oels, A. 2003. Evaluating stakeholder participation in the transition to sustainable development: Methodology, case studies, policy implications. NJ: Transaction Publishers.

Pradhananga, N. and C. Landorf. 2008. Stakeholder participation at World Heritage Sites: An analysis of the past and present conservation systems of the Kathmandu Valley World Heritage Site. http://www.guthiaustralia.org/files/Full\%20Paper\%20 Heritage\%202008.pdf (accessed 17 September 2013).

Pumar, E. S. 2005. Social networks and the institutionalization of the idea of sustainable development. International Journal of Sociology and Social Policy 25(1/2): 63-86. https://doi.org/10.1108/01443330510791298 
Scott, J. 1991. Social network analysis: A handbook. London: SAGE Publications.

Scott, J. and G. Marshall. 2005. Oxford dictionary of sociology. Oxford: Oxford University Press.

Sharma, S. and I. Henriques. 2005. Stakeholder influences on sustainability practices in the Canadian forest products industry. Strategic Management Journal 26: 159-180. https://doi.org/10.1002/smj.439.

United Nations World Commission on Environment and Development (UNWCED). 1987. Our common future. Switzerland: WCED. http://www.un-documents.net/ourcommon-future.pdf (accessed 25 April 2017).

United Nations Development Programme (UNDP). 1997. Governance for sustainable human development, A UNDP policy document. http://www.pogar.org/ publications/other/undp/governance/undppolicydoc97-e.pdf (accessed 25 April 2017).

United Nations Economic and Social Council. 2006. Definitions of basic concepts and terminologies in governance and public administration. Committee of Experts on Public Administration, Fifth Session, New York, Agenda Item 5. 27-31 March. http://unpan1.un.org/intradoc/groups/public/documents/un/unpan022332.pdf (accessed 25 April 2017).

UNPAGLOSSARY. n.d. UN public administration glossary. http:/www.unpan.org/ Directories/UNPAGlossary/tabid/928/Default.aspx (accessed 25 April 2017).

Wasserman, S. and K. Faust. 1994. Social network analysis: Methods and applications. Cambridge: Cambridge University Press. https://doi.org/10.1017/ CBO9780511815478.

Williard, T. 2009. Social networking and governance for sustainable development. International Institute for Sustainable Development. https://www.iisd.org/ pdf/2009/social_net_gov.pdf (accessed 25 April 2017).

World Bank. 1991. Managing development: The governance dimension. A discussion paper. Washington, DC: The World Bank. http://documents.worldbank.org/ curated/en/884111468134710535/pdf/34899.pdf (accessed 25 April 2017). 